\title{
Gateways, portails and Zugänge: a survey of some European national legal resources on the Internet
}

\section{Paul Norman}

Reference and Online Services Librarian, Institute of Advanced Legal Studies

Although the United Kingdom has been a member of the European Union for three decades, there has so far been little reference to Continental law and legal systems in British law library literature. I hope that these notes will help to begin filling that gap.

My plan is to highlight the main Internet legal resources for a selection of European jurisdictions. Limitation on both time during the original "live" presentation, and space in these pages, means that I can cover only the four major countries - France, Germany, Italy and Spain. Perhaps future instalments might cover some other countries. I have however included something on two "domestic" legal systems, Scotland and the Channel Islands, which are sometimes the subject of enquiries to IALS from London-based law firms and are in many respects closer to the civil law, rather than the common law family.

All the sites mentioned are freely available, but some restrict free use to noncommercial users, and some may contain specific areas that are on subscription.

Before coming to specific sites for each country, I should mention a number of general guides and gateways to foreign law.

\section{Guides}

\section{LLRX}

LLRX, the Law Library Resource Xchange, at http://llrx.com, is a respected and wide-ranging free Web journal founded and edited by Sabrina I. Pacifici, a law firm librarian in Washington D.C. It covers a broad range of topics including technology and legal research, current legal developments, reviews of websites, software and database services. While mainly dealing with American issues, it includes a Resource Centre on Foreign and Comparative Law. This contains articles on several countries, some of them that one might describe as "difficult" - Croatia, Estonia, Kazakhstan but also what may be termed the European "big six" - Belgium, France, Germany, Netherlands, Spain and Italy. These are good introductions to the legal framework, with many hyperlinks to online resources.

\section{Globalex}

Developed as part of the Hauser Global Law School program at New York University School of Law, this is another collection of articles on legal research in foreign and international law. Again, there are items on hard-to-find materials - Albania, Mail, Belarus, as well as the big six. Some of the articles are in fact updates of versions formerly in LLRX, presumably by amicable agreement of all concerned. URL: http://www.nyulawglobal.org/globalex/index.html I shall refer to Globalex in the following paragraphs without repeating the long web address. 


\section{IALS guides}

In a modest way, we at the Institute have been putting together online guides to European national legal literature. Originating in surveys of our own collections done in the early 80 s, they have been brought up to date and now include references to online resources, but continue to reflect the materials available at the Institute. As well as the "six", there are guides for Ireland, Luxembourg, the UK and the USA. URL: http://www.ials.sas.ac.uk/library/guides/research_guides.htm

\section{Gateways}

\section{SOSIG}

The Social Science Information Gateway, edited by staff at Bristol University Law Library and IALS, provides a gateway to worldwide legal websites that can be searched or browsed. A brief description of content and ownership is provided for each site. From the front page of the Law section at http://www.sosig.ac.uk/law there is a link to "Other jurisdictions" (outside the UK) and all European countries are represented, with obviously varying amounts of content. Where there are many resources, a quick guide on the left of the page points to key types such as legislation or law reports.

\section{Worldlii}

Wordlii (World Legal Information Institute) is part of the international collection of freely accessible legal online resources, which began in Australia with AUSTLII and includes BAILII for the British Isles. As well as actual databases it includes, in its "Catalog" area, a list of links to information for every country in the world. There are two separate regional sub-groups for Western Europe and Eastern Europe. The front page for each country lists links to resources by type (case law, government, law reform, legislation etc.) and by subject. But most important for present purposes, there is a list of the main general legal websites and portals. The entries are very brief, usually containing just one line of description. URL: http://www.worldlii.org

\section{Running searches in foreign language databases}

When using search templates on foreign websites, diacriticals are sometimes mandatory. For instance, if one is searching for the Spanish Civil Code in a "type of document" field, it may be necessary to enter código with an accented o.

\section{France}

The Globalex article on Researching French Law, added in May 2005, provides a good general introduction to the structure and workings of the legal system. It was written by Stéphane Cottin and Jérome Rabenou of the French Constitutional Council. On the same site, Emmanuel Barthe (whose own web pages are mentioned below) discusses French law on the Internet - The Basics and Free Resources. This too was added in May 2005.

The best place to find legal texts is probably the official Légifrance website at http://www.legifrance.gouv.fr. This provides clear links to legislation, including the codes. Many of the important codes, for example civil, commercial, penal, intellectual property, are available in English translation The case law of two of the highest courts: the Supreme Court (Cour de Cassation) and Council of State (Conseil d'Etat - 
the supreme administrative court) is available from the 1960s to date. The Constitutional Council (Conseil Constitutionnel) has a file of its decisions from the beginning (1958) on its own website at http://www.conseil-constitutionnel.fr.

Two general portals providing an overview of legal websites are worth mentioning. Droit.org at http://droit.org is non-profit portal to French law run by a group of lawyers and academics, and hosted at the Paris School of Mines. Much of the site unfortunately has not been updated since about 2001, and some links no longer work, but there are still up to date links to legislation and cases, mainly on the Légifrance website. Precisement.org http://www.precisement.org is described by its editor Emmanuel Barthe, a law firm librarian and legal information specialist, as a legal "blog", with the usual personal journal of useful discoveries that is well worth exploring. It is his section "Internet juridique: les sites Web incontournables" which lists general and specialized French legal websites. His description of the content of Légifrance is particularly clear.

Mention should be made of Droit francophone http://droit.francophonie.org, a guide in SOSIG style to online legal resources in francophone countries. It is affiliated to the WORLDLII family of free legal information, and has a link on the WORLLII front page. It is edited by a team at the University of Montréal under the auspices of the Intergovernmental Agency of Francophone Countries.

JusData http://www.jusdata.info is an interesting example of French-German cooperation in legal information and resources. It includes a selection of statutes of either country, in parallel French and German text, and is maintained jointly by the Universities of Montpellier and the Saarland.

\section{Germany}

The main Globalex article on Germany concentrates on sources of English translations of German business and commercial laws. Emphasis is on printed sources, though there are useful links to international online resources that one might not think of, for example WIPO for national intellectual property legislation and Natlex, the International Labour Organization's database of employment and related human rights legislation.

The State Library in Berlin provides an online catalogue of German legal resources and websites, under the title Virtuelle Fachbibliothek Recht (otherwise ViFa Recht): a Virtual Subject Library for Law at http://www.vifa-recht.de. Begun as a pilot project in November 2003, it went public at the end of 2004. It provides not only listings of books, articles, online journals etc., but also a SOSIG-style catalogue of internet resources (Internetquellen) in law. Arrangement is in a hierarchical structure under 16 subject headings, plus a "general" heading where a list of generic legal websites can be found. The structure is a little difficult to grasp, particularly the arrangement by type of resource; it is sometimes easier to use a keyword such as Rechtsprechung (case law) and /or the name of the court or government department required.

Just as SOSIG is part of a wider collection of gateways to several disciplines (the Research Discovery Network: RDN), ViFa Recht is one of several gateways that can be searched simultaneously at http://www.vascoda.de. (An English version of that page is available) 
The main free source for statutes is Gesetze im Internet at http://bundesrecht.juris.de/bundesrecht, which is a joint project of the Federal Ministry of Justice and the mainly commercial database provider Juris GmbH. It provides free access to selected full-text Federal legislation. It should be noted that in general, online versions of legislation are hosted by the government department responsible for them. Consequently, the front page of Gesetze im Internet has several links to the statute web pages of other ministries. However, it is not necessary to follow this path, as there is a complete list (Gesamtliste) in alphabetical order, as well as a full text search capability.

Both the Constitutional Court at http://www.bundesverfassungsgericht.de and Supreme Court at http://www.bundesgerichtshof.de maintain freely accessible online collections of their decisions, the former from 1998 and the latter from 2000 (in PDF format). Some other national courts provide selected decisions, but generally speaking case law is made available through subscription services.

Of special interest to English-speaking researchers is the German Law Archive http://www.iuscomp.org/gla/ hosted by Gerhard Dannemann of the Institute of European and Comparative Law at the University of Oxford. It includes an ever expanding collection of English translations of statutes and case law. Just as useful is a portal for many and various sources of translated texts. It is called German Laws in English Translation and is provided by a firm of (British) legal translators in Bonn at http://www.words-worth.de/robin/german-law/

\section{Italy}

The Globalex article, written by Emilio Fameli, Research Director of ITTIG (part of the Italian National research Council) and his colleague Fiorenza Socci, was published in March 2005. It is extremely detailed, running to the equivalent of 55 printed pages, and is full of hyperlinks to useful online resources.

ITTIG itself (the Institute of Legal Information Theory and Techniques) has a website with an English front page at http://www.ittig.cnr.it/IndexEng.htm. In its Databases and Guides section is Diritto Italia, a guide to Italian legal resources on the internet, including normativa (legislation) and giurusprudenza (case law).

The best source for statutes is probably Normeinrete (i.e. Norme in Rete: statutes on the net) at http://www.normeinrete.it. It is provided jointly by the Ministry of Justice and CNIPA, a research centre within the Ministry of Innovation and Technology. Coverage is quite comprehensive (national legislation since 1904, regional since 1948) and there is a detailed search template offering several search options.

\section{Spain}

Olga Cabrero's Globalex article, dated February 2005, provides a good general introduction and includes hyperlinks to government departments, university law schools and the legal profession.

The website of the Official Gazette (Boletin Oficial del Estado: English language front page at http://www.boe.es/g/eng/ ) has a database of legislation since 1968 called Iberlex, with national, regional and EU laws. There is a separate file called 
Gazeta, which is a historical file of the $B O E$ from 1875 to 1967 . The text has no hypertext links, and annotations are only available by subscription.

An easier to use resource is Noticias Jurídicas at http://noticias.juridicas.com. This is a well-organized portal from Leggio, an online publishing company associated with Editorial Bosch. It provides free access to its own texts of the "most important" legislation as amended, and with hyperlinks. Its extensive list of links to legal resources can be searched by subject area, geographical area or type of institution, or indeed combinations of these groups.

\section{Scotland}

The most ambitious web guide to Scots law on the net that I have found is Scottish Law Online http://www.scottishlaw.org.uk/, an independent site created by Kevin Crombie, a young Englishman with a Glasgow LLB. It is wide-ranging, being aimed at lawyers, students, academics and the public. The front page gives a very clear picture of the type of material and links available.

Another useful site is edited by John Mitchell QC, an advocate based in Edinburgh. Much of it relates to his own interests of public and administrative law, I.T. law and jurisdiction, and in fact I discovered his useful article on Scottish and European Civil Jurisdiction when looking for material on that issue. But he also has a page of Scottish Law and Legal System Links under the "Miscellany" heading. He has imported hyperlink listings of recent Court of Session opinions, as well as links to the search page on the Scottish Courts website.

URL: http://www.jonathanmitchell.info/index.html

\section{Channel Islands}

There appear to be no web guides or portals to Channel Islands law, but a good introduction to the law of small jurisdictions is provided by Andrew Grossman on Globalex. His title is Finding the Law: the Micro-States and Small Jurisdictions of Europe.

The Jersey Legal Information Board's site at http://www.jerseylegalinfo.je, now hosts the Revised Edition of the Laws, which came into force on July $1^{\text {st }} 2005$. As new revised editions of each law are prepared, a file of superseded revised editions will be built up. A comprehensive file of laws as enacted is also maintained. As to case law, the Jersey Law Reports, which began in 1985, are being gradually loaded on to the site. The years 1985 to 2002 are already available. A file of unreported judgments begins with 1997, and there are plans to begin adding cases from the series Jersey Judgments, which ran from 1950 to 1984 . Other pages on the site include legal information for the public, a directory of law firms and a student area with access to past examination papers.

The States of Guernsey (i.e. its Parliament) website at http://www.gov.gg is developing a collection of important laws, and several company and commercial ones are already available. This is an initiative of the Law Officers of the Crown, and at the moment (Autumn 2005) the "click trail" from the front page is Government (opens a dropdown list) - Law Officers - Legislation. Current areas linked from the bottom of the Legislation page are Banking, Partnership, Companies and Security Interests, with amended versions of the laws. It should be noted that financial services legislation is 
on the Financial Services Commission website at http://www.gfsc.gg. Under the Legislation heading is a page of links both to the 1987 statute governing the Commission itself, and "Legislation and Standards pertinent to the Finance Sector". The list is not exhaustive, and some of the listed titles are not hyperlinked, but the hyperlinks are to up-to-date PDF copies.

Finally, there are two law firm websites that provide useful "current awareness" information. Bedell Cristin at http://www.bedellcristin.com has a freely accessible Information Services area, which includes a Legislation Update and Jersey Judgments with summaries of selected judgments under nineteen subject headings. Ogier \& Le Masurier at http://www.ogier.com has updaters and guides under a Publications tab. There is for example an eleven-page guide to Companies in Guernsey.

\section{Conclusion}

This has been a brief and very selective excursion in to foreign territory, and readers who explore the introductory guides mentioned at the beginning will find several more resources, both public and private, which may reward their curiosity. The Internet being what it is, new ones will arrive and others may fail for lack of funding. But I hope at least that I have provided some useful pointers to areas of law that are increasingly relevant to the British legal and legal information community. 